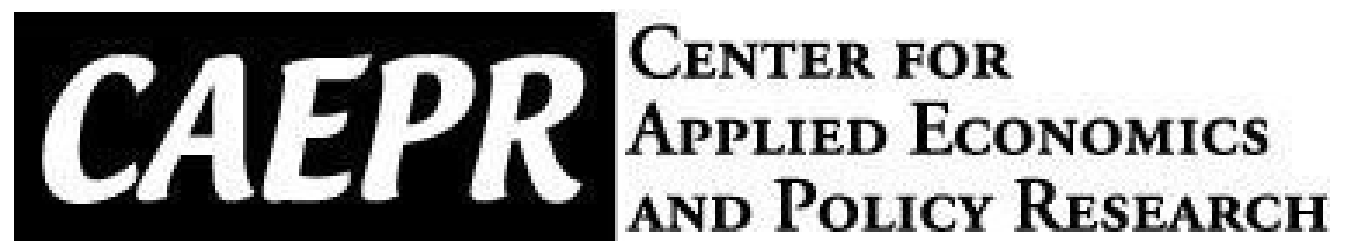

\author{
CAEPR \\ Working Paper \\ \#2017-012
}

\title{
Financial Crises and The Role of Debt Maturity for Emerging Economies
}

\author{
Hewei Shen \\ Indiana University
}

June 2, 2016

This paper can be downloaded without charge from the Social Science Research

Network electronic library at https://papers.ssrn.com/abstract_id=3068302

The Center for Applied Economics and Policy Research resides in the Department of Economics at Indiana University Bloomington. CAEPR can be found on the Internet at: http://www.indiana.edu/ caepr. CAEPR can be reached via email at caepr@indiana.edu or via phone at 812-855-4050.

(C)2017 by Hewei Shen. All rights reserved. Short sections of text, not to exceed two paragraphs, may be quoted without explicit permission provided that full credit, including (C) notice, is given to the source. 


\title{
Financial Crises and The Role of Debt Maturity for Emerging Economies *
}

\author{
Hewei Shen ${ }^{\dagger}$
}

June 2, 2016

\begin{abstract}
This paper studies the role of debt maturity for small open economies subject to endogenous financial crises. It uses an off-the-shelf two-sector DSGE model featuring collateral constraints and endogenous financial crises but allows the duration of the bond in the economy to vary. This model generates a trade-off between the borrowing cost and insurance benefit of a long-term bond. On one hand, it is more costly for small open economies to borrow through the longterm bond than the short-term bond. On the other hand, a long-term bond also provides an insurance benefit against aggregate shocks and the probability of financial crises declines monotonically in the duration of the bond. As a result, the quantitative analysis shows that the ex-ante welfare is maximized when the duration of the bond in the economy is seven quarters and this result sheds some light on why emerging market economies adopt controls on short-term capital flows.
\end{abstract}

Keywords: Bond Duration, Credit Constraints, Financial Crises.

JEL Classification: D62, F34, F41, G01

${ }^{*}$ Committee Members: Juan Carlos Hatchondo (Chair), Eric Leeper and Amanda Michaud. I am grateful to my advisors for their continuous encouragement and support.

${ }^{\dagger}$ Department of Economics, 105 Wylie Hall, 100 S. Woodlawn Ave Bloomington,IN 47405. Email: heshen@indiana.edu 


\section{Introduction}

During recent decades, many emerging market economies with less developed financial markets were hit by financial crises and experienced large drops in output and depreciation of local currencies, such as 1982 Chile debt crisis, 1997 Asian crisis and 1994 Mexico Peso crisis. Many economists attribute such financial crises in the emerging market economies to large and short-term capital inflows. Magud et al. (2011) points out that "hot money" can be particularly troubling for developing countries and "the sudden injection of funds into a small market can cause an initial dislocation that is mirrored by the strains associated with their withdrawal". Consequently, Magud et al. (2011) suggests that developing countries should adopt capital controls to alter the composition of capital inflow towards longer maturity flows.

To avoid the problem caused by "hot money", a number of emerging economies have adopted capital controls on short-term capital inflows. Table 1 is a list of the controls on short-term capital flows in selected countries. One famous example is that Chile set up an unremunerated reserve requirement (URR) ${ }^{1}$ in 1991 at a 20 percent rate (subsequently raised to 30 percent) and the deposit period was set at one year. This restriction deterred short-term capital inflow and successfully shifted the composition of capital inflow toward longer maturity until the requirement was lifted in $1998^{2}$. As shown in table 1, many other emerging market economies adopted similar capital controls that aim to regulate the shortterm borrowing and alter the maturity of capital inflows. The popularity of such capital flow regulation draws many economists' attention and there are abundant empirical papers that assess the effects of such regulations. However, we still lack a benchmark model to understand why such regulations can help stabilize the economies and prevent financial crises. Consequently, it is difficult to evaluate the merits of such regulation without a thorough understanding of its underlying mechanism. The goal of this paper is to fill the gap by studying the role of debt maturity in a small open economy model with endogenous financial crises.

This paper studies the role of debt maturity of small open economies using a model with credit constraints and endogenous financial crises. There is a continuum of private

\footnotetext{
${ }^{1}$ Unremunerated reserve requirement requires that part of the inflow be deposited in an unremunerated account for a period of time and is subject to penalty if the deposit is withdrawn early.

${ }^{2}$ There are a lot of empirical papers that assess the effect of Chile's capital control. For example, ValdésPrieto and Soto (1998), Larraín et al. (1997), Laurens and Cardoso (1998), Edwards (1999) and De Gregorio et al. (2000) find that Chile's URR successfully altered the composition of capital inflow toward longer maturity. On the other hand, Reinhart et al. (1998) and Gallego et al. (1999) only find the short-term effect of Chile's URR requirement. For a survey of the papers that evaluate the effectiveness of the capital controls adopted by emerging market economies, please see Ostry et al. (2010) and Magud et al. (2011)
} 
Table 1: Controls on Short-Term Capital Inflows of Selected Countries

\begin{tabular}{|c|c|c|}
\hline Country & Year & Controls \\
\hline Brazil & 1993-97 & $\begin{array}{l}\text {-Administrative controls (outright prohibitions against, or min- } \\
\text { imum maturity requirements for, certain types of inflows) }\end{array}$ \\
\hline Chile & 1991-98 & $\begin{array}{l}\text { - Introduced URR of } 20 \% \text { on foreign borrowing and deposit } \\
\text { time was set at } 1 \text { year, later extended to cover nondebt flows, } \\
\text { American Depository Receipts, and potentially speculative } \\
\text { FDI. }\end{array}$ \\
\hline \multirow[t]{2}{*}{ Colombia } & 1993-98 & $\begin{array}{l}\text { - Introduced URR of } 40 \% \text { on external borrowing (limited to } \\
\text { loans with maturities up to } 18 \text { months) and later extended to } \\
\text { cover certain trade credits. }\end{array}$ \\
\hline & 2007-08 & $\begin{array}{l}\text { - Introduced URR of } 40 \text { percent on foreign borrowing and port- } \\
\text { folio inflows. }\end{array}$ \\
\hline Malaysia & 1994 & $\begin{array}{l}\text { - Prohibition against sale of short-term debt securities and } \\
\text { money market instruments to nonresidents, and against com- } \\
\text { mercial banks engagement in non-trade-related swaps or for- } \\
\text { ward transactions with nonresidents. }\end{array}$ \\
\hline \multirow[t]{2}{*}{ Thailand } & 1995-96 & $\begin{array}{l}\text { - Reserve requirements, to be held in the form of non-interest } \\
\text { bearing deposits at the Bank of Thailand, on short-term non- } \\
\text { resident baht accounts were raised from } 2 \text { percent to } 7 \text { percent. } \\
\text {-Offshore borrowing with maturities of less than } 1 \text { year by com- } \\
\text { mercial banks, BIBF offices, finance companies and finance and } \\
\text { security companies will be subject to a } 7 \text {-percent minimum re- } \\
\text { serve requirement in the form of a nonremunerated deposit with } \\
\text { the Bank of Thailand. }\end{array}$ \\
\hline & 2006-08 & $\begin{array}{l}\text { - URR of } 30 \text { percent imposed on foreign currencies sold or ex- } \\
\text { changed against baht with authorized financial institutions (ex- } \\
\text { cept for FDI and amounts not exceeding US } \$ 20,000 \text { ). }\end{array}$ \\
\hline Indonesia & 2010 & $\begin{array}{l}\text { - Required holding period on foreign capital inflows and cen- } \\
\text { tral bank notes were increased to } 1 \text { month, and central banks } \\
\text { instruments with longer maturity ( } 6 \text { month and } 9 \text { month) were } \\
\text { introduced. }\end{array}$ \\
\hline South Korea & 2009 & $\begin{array}{l}\text {-Required domestic banks to fully match mid-to-long-term as- } \\
\text { set holdings with mid-to-long term funding. }\end{array}$ \\
\hline
\end{tabular}

Sources: Ostry et al. (2010) and Magud et al. (2011) 
agents who reside in the small open economy and issue a non-contingent (potentially longterm) bond to finance their consumption and the duration of the bond is exogenous. The borrowing is denominated in the international unit of account, i.e. tradable goods. The financial market is imperfect and the private agents' borrowing is constrained by the value of their collateral, which is in the form of the market value of current endowment income from both tradable and nontradable sectors, as in Mendoza (2002) and Bianchi (2011). The small open economy faces a counter-cyclical country interest rate and the interest rate increases with the aggregate debt level of the economy. Two externalities arise in this model: a bond price externality and a nontradable price externality. A bond price externality emerges as the private agents fail to take into consideration the effect of their borrowing decisions on the country interest rate and the price of bond. Similar to the models in the existing literature, this model also features a nontradable price externality ${ }^{3}$, which results from agents' failure to internalize the effect of their borrowing decision on the market value of their collateral. I then vary the duration of the bond in the economy and investigate how long-term bond can ameliorate the effect of these two externalities.

My quantitative analysis shows that the effects of both externalities are reduced when the duration of bond in the economy increases. The probability of crises monotonically decreases in the duration of bond in the model. Specifically, if the duration of bonds is prolonged from 1 quarter to 8 quarters, the probability of crises is reduced by nearly half. However, the welfare gain as a function of the duration of bond is hump-shaped and the welfare gain is maximized when the private agents live in an economy that the duration of bond is 7 quarters. I further investigate the benefit and cost of living in the economies with a bond with a longer maturity. Similar to the empirical findings in Broner et al. (2013), this model suggests that it is more expensive to borrow long-term than short-term. Therefore, the cost of long-term bond is that the private agents have to pay a higher interest rate when they are living in an economy with longer duration bonds. On the other hand, long-term bond provides an insurance benefit against unfavorable shocks. Since the country interest rate is countercyclical, private agents' outstanding liability also shrinks when an unfavorable endowment shock hits the economy. Despite the fact that the bond payments are non-contingent, longterm bond effectively shifts some of the aggregate risk toward lenders and provides a hedge benefit to the private agents. Lastly, I conduct two counterfactual experiments to show that the hedge benefit of the long-term bond is greater in an economy with financial amplification effect.

This paper sheds some light on why the emerging market economies adopt controls on

\footnotetext{
${ }^{3}$ Bianchi (2011), Jeanne and Korinek (2010) and Korinek (2010) provide detailed explanations on this nontradable price externality and propose corresponding policy prescriptions.
} 
short-term capital flows. In addition, the model proposed in this paper captures the largely agreed on trade-off between the insurance benefit and borrowing cost of long-term bond. Such result suggests that a carefully chosen bond duration in the economy can help prevent financial crises and enhance welfare. Therefore, this model can serve as a useful tool to study the capital controls for small open economies in future research.

\subsection{Related Literature}

This paper relates to a series of papers that propose to use ex-ante macro-prudential policies to prevent financial crises and improve welfare in small open economies. The existing literature, such as Mendoza (2002), Mendoza (2010) and Bianchi (2011) ${ }^{4}$, adopts a specific form of financial friction, an occasionally binding collateral constraint, to generate financial crises. These papers argue that, under this type of financial friction, private agents fail to internalize the effect of their borrowing decisions on the market value of their collateral, and consequently they tend to borrow "too much" compared to the optimal level. Such "overborrowing behavior" makes the private agents vulnerable to financial crises. As a result, the literature proposes to use a state-contingent tax to correct the externality and improve the ex-ante welfare. The model proposed in this paper is similar to the one used in Bianchi (2011) but I extend it to allow the duration of the bond in the economy to vary. In addition, in this paper I study how debt maturity can affect the probability of crises and the welfare of private agents in the economy.

This paper is also related to a series of papers that study the optimal maturity structure in a general equilibrium model. Angeletos (2002) shows that maturity structure can substitute for state-contingent debt. In addition, it can implement almost every Arrow-Debreu allocations with just non-contingent debt, with carefully chosen portfolios of non-contingent bonds. Similarly, Buera and Nicolini (2004) also shows that the theoretical conditions under which the complete market Ramsey allocation can be implemented with non-contingent debt of different maturities. Also, Bengui (2011) analyzes private debt maturity choices in a dynamic macroeconomic model in which financial frictions give rise to systemic risk in the form of amplification effects. It argues that long-term bond can provide an insurance benefit against shocks, but at extra cost. In this paper, long-term bond has a similar role and it can provide some hedge benefit against aggregate shocks in the economy.

Lastly, this paper also relates to the literature that studies the counter-cyclical country spreads among emerging market economies. Neumeyer and Perri (2005) finds that in a sample of emerging economies business cycles are more volatile than in developed ones,

\footnotetext{
${ }^{4}$ Some pioneering works in this literature includes Benigno et al. (2013), Korinek (2010), Jeanne and Korinek (2010), Bianchi and Mendoza (2011) and Mendoza and Bianchi (2015).
} 
real interest rates are counter-cyclical and lead the cycle. Similarly, Uribe and Yue (2006) decomposes the effect of various factors on the country spreads. It finds that country spread shocks explain about 12 percent of business-cycle movements in emerging economies and about 60 percent of the movements in country spreads are explained by country-spread shocks. In the model presented in this paper, the small open economy also faces a countercyclical country interest rate and I investigate the role of debt maturity in the presence of financial friction.

The paper is organized in the following way. Section 2 presents the model and discusses the externalities in competitive equilibrium. In section 3, I conduct quantitative analysis of the model and show the main results of this paper. In addition, I discuss the role of the debt maturity in this model and how the long-term bond attenuates the problem of externalities. Section 4 provides some concluding remarks.

\section{Model}

The model is similar to the one used in Bianchi (2011) but I allow the private agents to borrow through bond with duration which can be different from one-period. In this section, I describe the model environment and discuss the externalities in this model.

\subsection{Model Setup}

Time is discrete and denoted by $t \in\{0,1,2,3, \ldots\}$. There is a continuum of identical, infinitely lived private agents of measure unity who live in a small open economy. Each period, the private agents receive a tradable endowment $y_{T, t}$ and nontradable endowment $y_{N, t}$. The process for tradable endowment $y_{T, t}$ is stochastic and follows a finite-state firstorder Markov chain with state space $y_{T, t} \subset \mathbb{R}_{++}$and transition probability $\operatorname{Pr}\left\{y_{t+1}=y^{\prime} \mid y_{t}=\right.$ $y\}$. For simplicity, the nontradable endowment is fixed and the private agents receive the same nontradable endowment $y_{N, t}=y_{N}$ each period ${ }^{5}$.

Each private agent maximizes his expected utility and his preference is given by:

$$
\mathbb{E}_{0} \sum_{t=0}^{\infty} \beta^{t} \frac{c_{t}^{1-\gamma}}{1-\gamma}
$$

Here $\mathbb{E}_{0}\{\cdot\}$ is the time 0 expectation operator and $\beta$ is the discount factor. The utility function takes the constant relative risk aversion form, with risk aversion coefficient $\gamma . c_{t}$ is a composite good and is produced using CES combination technology from tradable good

\footnotetext{
${ }^{5}$ Having a stochastic nontradable endowment process will not affect the result qualitatively.
} 
$c_{T, t}$ and nontradable good $c_{N, t}$ :

$$
c_{t}=\left[\omega c_{T, t}^{-\eta}+(1-\omega) c_{N, t}^{-\eta}\right]^{-\frac{1}{\eta}}
$$

The elasticity of substitution between tradable and nontradable consumption is given by $1 /(\eta+1)$ and $\omega \in(0,1)$ measures the private agents' relative preference for tradable goods.

Each period, the agents can borrow or save through a non-state-contingent bond denominated in the units of tradable goods. Following Hatchondo and Martinez (2009), I assume that a bond issued in period $t$ promises an infinite stream of coupon payments decaying at a constant rate $1-\delta$. Specifically, one unit of bond issued in period t pays 1 unit of tradable good in period $t+1,1-\delta$ units of tradable good in period $t+2$ and thus $(1-\delta)^{s-1}$ units of tradable good in period $t+s$. With this specification, the bond is a one-period bond if $\delta=1$ and a console if $\delta=0$. I use Macaulay definition of duration to calculate the duration of bonds. For the bonds specified in this framework, the Macaulay duration of a bond $D$ is given by:

$$
D=\frac{1+r^{*}}{\delta+r^{*}}
$$

where $r^{*}$ is the exogenous international interest rate.

For private agents, the bond duration parameter $\delta$ is exogenous and they face the following budget constraint in period $t$ :

$$
c_{T, t}+p_{t} c_{N, t}+q_{t} b_{t+1}=b_{t}+q_{t}(1-\delta) b_{t}+y_{T, t}+p_{t} y_{N}
$$

where $b_{t+1}$ denotes the bond holding that the private agents choose at the beginning of period $t$. Specifically, $b_{t+1}$ is the coupon payment that the bond will deliver in period $t+1$. $q_{t}$ is the price of one unit of decaying infinite coupon series $\left(b_{t+1}=1\right)$ in period $t$ and it is discussed in detail in the next section. In each period, the existing bond pays a coupon payment $b_{t}$ and the value of the remaining bond is given by $q_{t}(1-\delta) b_{t}$. $p_{t}$ is the relative price of the nontradable good in units of tradable good. The private agents take both bond price $q_{t}$ and relative price of nontradable good $p_{t}$ as given.

The financial market in this economy is not only incomplete but also imperfect. As the agents borrow on international market, the value of debt cannot exceed a fraction $\kappa$ of the marked-to-market value of the income in that period. Specifically, the credit constraint is given by:

$$
-q_{t} b_{t+1} \leq \kappa\left(y_{T, t}+p_{t} y_{N}\right)
$$

The credit constraint is similar to the one specified in Bianchi (2011) and it arises from informational and institutional frictions when the agents are borrowing from the international 
financial market ${ }^{6}$. Following the current financial crises literature, I abstract from modeling this financial friction explicitly and in this paper I focus on how debt maturity will influence the welfare of emerging market economies.

\subsection{Country interest rate and bond price}

In this paper I follow Álvarez-Parra et al. (2013) and assume the country interest rate to be correlated with the aggregate bond position and endowment shock in the economy. The country interest rate $r_{t}$ that private agents face when they borrow takes the following pattern:

$$
r_{t}=r^{*}+\chi\left[\exp \left(-\frac{b_{t+1}}{r^{*}+\delta}\right)-1\right]+\phi\left(y_{T, t}-\bar{y}_{T}\right)
$$

where $\bar{y}_{T}$ is the mean of the tradable endowment process. As shown in (5), the country interest rate is determined by three components. The first component is the exogenous international interest rate $r^{*}$, which is fixed in this model. The second component $\chi\left[\exp \left(-b_{t+1} /\left(r^{*}+\delta\right)\right)-1\right]$, with $\chi>0$, implies that the country interest rate increases with the aggregate debt level in the small open economy, which is a common assumption in the small open economy literature. Here $-b_{t+1} /\left(r^{*}+\delta\right)$ is the present value of all future coupon payments discounted by the exogenous international interest rate $r^{*}$ and I refer it as the face value of the bond after issuing new bond at time $t$. The third component, $\phi\left(y_{T, t}-\bar{y}_{T}\right)$, with $\phi<0$, potentially generates a counter-cyclical country interest rate that is typically observed in emerging market economies (Neumeyer and Perri (2005)) ${ }^{7}$.

In this model, (5) is a reduced form way to introduce a counter-cyclical country interest rate that increases with the indebtedness of the economy. I abstract from the explicit modeling the mechanism that generates such interest rate but focus on how a country interest rate in such pattern can affect the welfare of emerging economies as the maturity of bonds varies in this small open economy.

Lastly, the price of the bond is the present value of all future coupon payments discounted

\footnotetext{
${ }^{6}$ This type of collateral constraint is similar to the "margin call" assumption specified in Mendoza and Smith (2002). This type of collateral constraint assumes that the borrowing contract requires that the value of total amount of debt can never exceed a certain fraction of the market value of the collateral. If the market value of collateral drops and the collateral constraint (4) is violated, the borrowers is required to reduce the borrowing or even buy back some of the existing bonds in order to make (4) hold again.

${ }^{7}$ Uribe and Yue (2006) and Neumeyer and Perri (2005) study the counter-cyclical interest rate observed among emerging market economies in detail.
} 
by the country interest rate $r_{t}$. Specifically, it can be written as:

$$
q_{t}=E_{t} \sum_{i=1}^{\infty} \frac{(1-\delta)^{i-1}}{\prod_{j=0}^{i-1}\left(1+r_{j}\right)}
$$

As shown in (6), the bond price is negatively correlated with the sequence of country interest rates in the future $\left\{r_{t}, r_{t+1}, \ldots\right\}$. Since the country interest rate $r_{t}$ is potentially countercyclical, the bond price $q_{t}$ is potentially pro-cyclical. As a result, when the private agents issue long-term bonds, the market value of their outstanding debt, $q_{t}(1-\delta) b_{t}$, is also procyclical, providing an insurance benefit during economic downturn. Such insurance benefit of long-term bond will be discussed in detail in section 3.4.

\subsection{Competitive Equilibrium}

In this section I derive the optimality conditions for the private agents and formally define the competitive equilibrium. Then I discuss how financial crises arise endogenously in competitive equilibrium.

\subsubsection{Optimality Conditions for Competitive Equilibrium}

The bond duration parameter $\delta$ is exogenous and the private agents take the price of bond $q_{t}$ and relative price of nontradable good $p_{t}$ as given. Then the private agents' problem is to choose a stochastic sequence of $\left\{c_{T, t}, c_{N, t}, b_{t+1}\right\}_{t=0}^{\infty}$ to maximize their expected lifetime utility (1) subject to budget constraint (3) and credit constraint (4). The first order conditions with respect to $c_{T, t}, c_{N, t}$ and $b_{t+1}$ are:

$$
\begin{aligned}
U_{T}(t) & =\lambda_{t} \\
U_{N}(t) & =p_{t} \lambda_{t} \\
q_{t} \lambda_{t} & =\beta \mathbb{E}_{t}\left[1+q_{t+1}(1-\delta)\right] \lambda_{t+1}+\mu_{t}
\end{aligned}
$$

where $U_{T}$ and $U_{N}$ are the first derivatives of the utility function with respect to tradable and nontrdable consumption. $\lambda_{t}$ is the Lagrange multiplier associated with the budget constraint (3) and $\mu_{t}$ is the Lagrange multiplier associated with the borrowing constraint (4).

Combining (7) and (8), it yields the price of the nontradable good as a function of tradable and nontradable consumption:

$$
p_{t}=\frac{1-\omega}{\omega}\left(\frac{c_{T, t}}{c_{N, t}}\right)^{1+\eta}
$$


With $\eta>-1$, the relative price of nontradable good is an increasing function of tradable consumption $c_{T, t}$. Combining (7) and (9), it gives the intertemporal euler equation for private agents:

$$
U_{T}(t)=\beta \mathbb{E}_{t}\left[\frac{1+(1-\delta) q_{t+1}}{q_{t}} U_{T}(t+1)\right]+\mu_{t}
$$

When the borrowing constraint is not binding (e.g. $\mu_{t}=0$ ), equation (11) is just a common Euler equation that equates the marginal utility of tradable consumption in current period to the expected marginal utility of tradable consumption in the next period. However, as the borrowing constraint binds and the private agents are unable to borrow anymore (e.g. $\mu_{t}>0$ ), it drives a wedge between the current and next period marginal utility of tradable consumption.

In equilibrium, both tradable and nontradable goods markets must clear. Therefore, the market clearing conditions are given by:

$$
\begin{aligned}
c_{N, t} & =y_{N} \\
c_{T, t}+q_{t} b_{t+1} & =b_{t}+q_{t}(1-\delta) b_{t}+y_{T, t}
\end{aligned}
$$

\subsubsection{Definition of Competitive Equilibrium}

To define the competitive equilibrium, I write private agents' problem recursively. I denote the aggregate bond holding as $B$ and the agents' perceived law of motion of the aggregate bond holding as $\Gamma(\cdot)$. The state variables are aggregate bond holding $B$ and realized tradable endowment $y_{T}$. Therefore, the perceived law of motion of the aggregate bond holding is given by $B^{\prime}=\Gamma\left(B, y_{T}\right)$. The relative price of nontradable good $p\left(B, y_{T}\right)$ and bond price $q\left(B^{\prime}, y_{T}\right)$ also depend on these two state variables and follow equations (10) and (6). The private agents' problem thus can be written recursively as:

$$
\begin{aligned}
V\left(b, B, y_{T}\right) & =\max _{b^{\prime}, c_{T}, c_{N}} u\left(c_{T}, c_{N}\right)+\beta \mathbb{E} V\left(b^{\prime}, B^{\prime}, y_{T}^{\prime}\right) \\
\text { st. } c_{T}+p\left(B, y_{T}\right) c_{N}+q\left(B^{\prime}, y_{T}\right) b^{\prime} & =b+q\left(B^{\prime}, y_{T}\right)(1-\delta) b+y_{T}+p\left(B, y_{T}\right) y_{N} \\
-q\left(B^{\prime}, y_{T}\right) b^{\prime} & \leq \kappa\left(y_{T}+p\left(B, y_{T}\right) y_{N}\right) \\
B^{\prime} & =\Gamma\left(B, y_{T}\right)
\end{aligned}
$$

In the recursive formulation, I omit the time subscripts and denote all the next period variables with apostrophe.

Definition 1. A recursive equilibrium for the private agents' problem is defined by a pricing function for nontradable good $p\left(B, y_{T}\right)$, pricing function for bond $q\left(B^{\prime}, y_{T}\right)$, a perceived law of 
motion for the aggregate asset holding $\Gamma\left(B, y_{T}\right)$ and decision rules $\left\{\hat{c}_{T}\left(b, B, y_{T}\right), \hat{c}_{N}\left(b, B, y_{T}\right)\right.$, $\left.\hat{b}\left(b, B, y_{T}\right)\right\}$ with associated value function $V\left(b, B, y_{T}\right)$ such that:

1. Decision rules $\left\{\hat{c}_{T}\left(b, B, y_{T}\right), \hat{c}_{N}\left(b, B, y_{T}\right), \hat{b}\left(b, B, y_{T}\right)\right\}$ solve the recursive optimization problem of the private agents, given $p\left(B, y_{T}\right), q\left(B^{\prime}, y_{T}\right)$ and $\Gamma\left(B, y_{T}\right)$.

2. The perceived law of motion is consistent with the actual law of motion $\Gamma\left(B, y_{T}\right)=$ $\hat{b}\left(b, B, y_{T}\right)$.

3. Markets clear: $y_{N}=\hat{c}_{N}\left(b, B, y_{T}\right)$ and $\hat{c}_{T}\left(b, B, y_{T}\right)+q\left(B^{\prime}, y_{T}\right) \Gamma\left(B, y_{T}\right)=B+q\left(B^{\prime}, y_{T}\right)(1-$ $\delta) B+y_{T}$.

\subsubsection{Endogenous Financial Crises}

The 1997 Asian financial crisis and 1994 Mexico Peso Crisis are featured by large drops in output, consumption and depreciation of local currencies. In this model, financial crises with similar features can arise endogenously due to the presence of the credit constraint in the form of (4). In this section, I discuss the mechanism that can cause endogenous financial crises in this model. In the next few sections, I will show why bonds with longer duration can reduce the probability of crises in this model.

Assume that now a private agent is borrowing and the credit constraint is binding. An unfavorable endowment shock realizes and the agent has to cut tradable consumption $c_{T, t}$ since his borrowing ability is limited by the credit constraint. Since all the private agents in this economy are identical and they share the same endowment process, all of them cut tradable consumption $c_{T, t}$ at the same time. Then the pricing function of nontradable good (10) implies that a reduction of aggregate tradable consumption $c_{T, t}$ will cause a drop of the relative price of nontradables $p_{t}$, which will in turn reduce the market value of the collateral $\left(y_{T, t}+p_{t} y_{N}\right)$. Consequently, the agents' borrowing ability is further compromised, which in turn further reduces aggregate tradable consumption and thus relative price. Therefore, the effect of the initial unfavorable shock can be amplified when the credit constraint is binding and may cause a large drop in consumption and relative price of nontradable good. In current financial crises literature, nontradable good is frequently interpreted as the local currency and thus its price is interpreted as the real exchange rate of the local currency. As a result, the financial crisis events generated in this model are similar to the financial crises happened in Asia and Mexico, which both feature large drops in consumption, output and depreciation of local currencies. 


\subsection{Discussion of the Externalities}

In sections 2.3.1 and 2.3.3, I derive the optimality conditions for private agents and discuss how financial crises may arise endogenously. Notice that in competitive equilibrium the private agents take the relative price of nontradable good $p_{t}$ and bond price $q_{t}$ as given and do not take into consideration how their bond and consumption choices will affect $p_{t}$ and $q_{t}$. As a result, externalities arise in competitive equilibrium and the private agents may not choose the allocation that maximizes their welfare.

In this section, I consider a benevolent social planner's problem that can internalize the effect of borrowing decisions on the bond price and price of nontradables. By solving the social planner's problem and comparing the results with competitive equilibrium, I can identify the effects of the externalities and study how the introduction of long-term bond can mitigate the externality problem and enhance private agents' welfare. For the social planner's problem, I assume that the social planner can directly choose the aggregate debt level subject to the credit constraint but internalizes the effects of his borrowing decision on bond price and price of nontradables. Specifically, the social planner realizes that (a) a reduction of the tradable consumption will lead to a drop of relative price of nontradables (b) a decrease in asset position will increase the country interest rate. As a result, the social planner solves the following recursive problem:

$$
\begin{aligned}
V\left(B, y_{T}\right) & =\max _{B^{\prime}, c_{T}} u\left(c_{T}, y_{N}\right)+\beta \mathbb{E} V\left(B^{\prime}, y_{T}^{\prime}\right) \\
\text { st. } c_{T}+q\left(B^{\prime}, y_{T}\right) B^{\prime} & =B+q\left(B^{\prime}, y_{T}\right)(1-\delta) B+y_{T} \\
-q\left(B^{\prime}, y_{T}\right) B^{\prime} & \leq \kappa\left[y_{T}+\frac{1-\omega}{\omega}\left(\frac{c_{T}}{y_{N}}\right)^{1+\eta} y_{N}\right] \\
r=r^{*}+\chi & {\left[\exp \left(-\frac{B^{\prime}}{r^{*}+\delta}\right)-1\right]+\phi\left(y_{T}-\bar{y}_{T}\right) } \\
q\left(B^{\prime}, y_{T}\right) & =\mathbb{E}\left(\frac{1+(1-\delta) q\left(B^{\prime}, y_{T}^{\prime}\right)}{r}\right)
\end{aligned}
$$

Notice that the social planner's problem is similar to the private agents' but he internalizes the pricing function (10) and plug it into its credit constraint (20). In addition, the social planner internalizes the effect of aggregate borrowing behavior on country interest rate, as shown in (21). I use the superscript 'sp' to denote the lagrange multipliers for the social planner. When the borrowing constraint is not binding, the intertemporal Euler equation for the social planner can be expressed as: 


$$
\begin{aligned}
U_{T}(t)[1+\underbrace{q_{t}^{-1}}_{>0} & \underbrace{\frac{\partial q_{t}}{\partial B_{t+1}}}_{>0} \underbrace{\left(B_{t+1}-(1-\delta) B_{t}\right)}_{<0 \text { when issuing new debt }}] \\
& =\beta \mathbb{E}_{t}\left[\frac{1+q_{t+1}(1-\delta)}{q_{t}}(U_{T}(t+1)+\underbrace{\Psi_{t+1}^{s p} \mu_{t+1}^{s p}}_{\left.>0 \text { if } \mathbb{E}_{t} \mu_{t+1}^{s p}>0\right)})\right]
\end{aligned}
$$

Where $\Psi_{t}^{s p} \equiv \kappa(1+\eta)\left(p_{t} c_{N, t} / c_{T, t}\right)(1+\eta)>0$ shows the first derivative of the collateral value with respect to tradable consumption $c_{T, t}$. For comparison, the Euler equation for private agents when the borrowing constraint is not binding is:

$$
U_{T}(t)=\beta \mathbb{E}_{t}\left[\frac{1+(1-\delta) q_{t+1}}{q_{t}} U_{T}(t+1)\right]
$$

By comparing the intertemporal euler equations of social planner and private agents, the social planner's euler equation has two more components than private agents' euler equations: $q_{t}^{-1}\left(\partial q_{t} / \partial B_{t+1}\right)\left(B_{t+1}-(1-\delta) B_{t}\right)$ and $\Psi_{t+1}^{s p} \mu_{t+1}^{s p}$. These two components are from the fact the the social planner internalizes how the decision on aggregate debt position $B^{\prime}$ will affect the bond price and relative price of nontradables, respectively. In the rest of this paper, I refer these two externalities as bond price externality and nontradable price externality. Next I discuss how long-term bond can mitigate the effect of the externalities.

The first difference between euler equations of the social planner and private agents is $q_{t}^{-1}\left(\partial q_{t} / \partial B_{t+1}\right)\left(B_{t+1}-(1-\delta) B_{t}\right)$, representing that the social planner is reluctant to change the aggregate asset position in order to avoid a large change of bond price, which I refer as bond price externality in this paper.

Remark 1. For the economy with one-period bond $(\delta=1)$, the social planner chooses a higher asset position than private agents in order to preserve a higher bond price.

For the economy with one-period bond $(\delta=1)$, all the bonds expire each period and the agents in the economy need to rollover all the debt each period. Therefore, $q_{t}^{-1}\left(\partial q_{t} / \partial B_{t+1}\right)\left(B_{t+1}-\right.$ $\left.(1-\delta) B_{t}\right)<0$ is negative if the social planner chooses to borrow at all $\left(B_{t+1}<0\right)$. As a result, the marginal utility of consumption in period $t$ is smaller for social planner and thus he decides to choose higher asset position than private agents in order to avoid a large decline of bond price.

The effect of the bond price externality discussed above diminishes with the duration of bond. In the economies with long-term bond $(\delta<1)$, the agents only need to rollover a fraction $(\delta)$ of the debt each period. Specifically, the larger the duration of bond is (the 
smaller $\delta$ is), the smaller the fraction of debt that the agents need to rollover each period (the smaller $\left.\left(B_{t+1}-(1-\delta) B_{t}\right)\right)$. Also, $q_{t}$ increases in bond duration and thus $q_{t}^{-1}$ decreases in bond duration. Lastly, the numerical analysis part shows that the first derivative of bond price with respect to aggregate asset position $\left(\partial q_{t} / \partial B_{t+1}\right)$ is increasing, but only slightly, in the bond duration. As a result, in equilibrium $q_{t}^{-1}\left(\partial q_{t} / \partial B_{t+1}\right)\left(B_{t+1}-(1-\delta) B_{t}\right)$ as a whole decreases in the duration of bond and thus the bond price externality is mitigated in the economies with long-term bond.

The second difference between euler equations of the social planner and private agents is $\Psi_{t+1}^{s p} \mu_{t+1}^{s p}$, representing that the social planner internalizes the effect of its bond decision on nontradable price $p_{t}$, which I refer as nontradable price externality in this paper.

Remark 2. If there is a positive possibility that the credit constraint will bind in next period, the social planner chooses a higher asset position than private agents. ${ }^{8}$

To see why the social planner chooses a higher asset position, notice that $\mathbb{E}_{t} \Psi_{t+1}^{s p} \mu_{t+1}^{s p}$ is strictly positive when the social planner perceives that there is a positive possibility that the credit constraint will bind in period $t+1$. As shown in equation (23), the marginal benefit of saving in period $t+1$ is increased by the extra term $\Psi_{t+1}^{s p} \mu_{t+1}^{s p}$ so that the social planner values the next period marginal utility more than private agents since he understands that extra saving will also improve the price of nontradables. Thus he would choose an allocation (higher asset position in this case) in order to reduce the probability of having a binding credit constraint in the next period. Therefore, equation (23) implies that the choice of bond duration should be aimed to reduce the probability of having a binding credit constraint in order to reduce the welfare loss from financial crises. Since it is not possible to show it analytically that how change of debt maturity can achieve this goal, I will solve this model numerically and show that the effect of nontradable price externality can be mitigated with long-term bond in the next section.

To summarize, bond price externality and nontradable price externality arise in competitive equilibrium so that the private agents fail to choose the allocation that maximizes their welfare. I have shown that the effect of bond price externality can be reduced in the economies with long-term bond since the private agents only need to rollover a fraction of their debt each period. To mitigate the effect of nontradable price externality, the borrowing decision should aim to reduce the probability of having a binding constraint in order to

\footnotetext{
${ }^{8}$ The nontradable price externality has been thoroughly studied in the current financial crisis literature. In the literature, the authors propose to levy a state-contingent Pigouvian tax on borrowing. See Bianchi (2011), Jeanne and Korinek (2010) and Korinek (2010) for a discussion of how to correct the pecuniary externality with a Pigouvian tax. However, in this paper, I focus on the role of debt maturity on the welfare of an economy so I do not include a discussion of the pigouvian tax.
} 
Table 2: Parameter Values

\begin{tabular}{clll}
\hline Parameter & Description & Value & Source \\
\hline \hline$\beta$ & Discount Factor & 0.971 & Benigno et al. (2013) \\
$r^{*}$ & Exogenous Interest Rate & 0.01 & Benigno et al. (2013) \\
$\gamma$ & Risk Aversion Coefficient & 2 & Standard \\
$1 /(1+\eta)$ & Elasticity of Substitution & 0.83 & Bianchi (2011) \\
$\kappa$ & Collateral Constraint Coefficient & 0.23 & Average NFA-GDP -14\% \\
$\omega$ & Weight on tradable in CES & 0.31 & Bianchi (2011) \\
$\chi$ & Borrowing Premium Coefficient & 0.0105 & Average Country Premium 3.6\% \\
$\phi$ & Counter-cyclical Rate Coefficient & -0.11 & Premium During Crises 9.0\% \\
$\rho$ & Endowment Process & 0.75 & Mexico Data \\
$\sigma$ & Endowment Process & 0.0455 & Mexico Data \\
$\delta$ & Bond Duration Parameter & Free & \\
\hline
\end{tabular}

reduce the probability of financial crises. I will show how a change of debt maturity can achieve this goal in the next section.

\section{Quantitative Analysis}

In this section, I describe the calibration of this model and solve this model numerically with different values of debt maturity parameter $\delta$. Then I show the results and discuss the cost and benefit of long-term bond in this economy with credit constraint.

\subsection{Calibration}

I calibrate the model using quarterly data of Mexico from 1994Q1 to 2014Q4 and each period in the model corresponds to one quarter. I pick Mexico since it is an emerging economy and it suffered from its financial crisis in 1994, which is the main focus of this paper. Also, many quantitative works in the financial crisis literature, such as Bianchi (2011), Benigno et al. (2013) and Mendoza (2010), also study Mexico Peso crisis. Therefore, I can borrow some parameter values from their work and compare the results in this paper to theirs. The calibrated parameter values are listed in table 2. Specifically, I set the discount factor to $\beta=0.971$ and the exogenous international interest rate $r^{*}=0.01$, which are close to the values in Benigno et al. (2013). The risk aversion parameter is set to $\gamma=2$ and it is a common value in DSGE literature. The elasticity of substitution between tradable and nontradable goods is chosen such that $1 /(1+\eta)=0.83$, which is the same value used in Bianchi (2011).

The coefficient on the collateral constraint $\kappa$ is set to 0.23 in order to target the average net 
foreign asset to GDP ratio in Mexico. The tradable goods preference parameter, $\omega=0.31$, is the same value used in Bianchi (2011). The country interest rate coefficients $\chi$ and $\phi$ are set to 0.0105 and -0.11 respectively, which yield an average country premium of $3.6 \%$ and country premium of $9 \%$ during financial crisis in the competitive equilibrium with one-period bond, which is consistent with the empirical findings in Broner et al. (2013).

I assume the tradable endowments follow an autoregressive process:

$$
\log \left(y_{T, t}\right)=\rho \log \left(y_{T, t-1}\right)+\varepsilon_{t}
$$

$\rho$ is the autoregressive coefficient and $\varepsilon_{t}$ is normally distributed with zero mean and standard deviation $\sigma$. I estimate $\rho$ and $\sigma$ from the OECD quarterly GDP data from 1994Q1 to 2014 Q4. I take log and HP-filter the GDP data before I estimate the autoregressive coefficient $\rho$ and the standard deviation $\sigma$. The estimated $\rho$ equals 0.75 and $\sigma$ is 0.0455 . Lastly, I make the bond duration parameter $\delta$ a free parameter in this model and study how the probability of crises and welfare varies with the duration of bond.

\subsection{Computation Method}

In this section I describe the computation methods that I use to solve this model. Firstly I discuss how I calculate the bond price $q_{t}$ and then I show the algorithm that I use to solve for the equilibrium. When calculating the price of bond $q_{t}$ for each state $b_{t+1}$ and $y_{T, t}$, I assume that the lenders expect the private agents to keep the same bond level forever rather than

form expectation on private agents' future bond holdings (e.g. I assume $b_{t+j}=b_{t+1} \forall j>1$ when forming expectations in equations (5) and (6)). The advantage of this assumption is that I can calculate the bond price for each $\left(b_{t+1}, y_{T, t}\right)$ easily and the bond price always converges. Chatterjee and Eyigungor (2012) points out that the price of long-term bond is very hard to converge in default model due to the dilution problem and the assumption allows me to avoid the convergence problem for long-term bonds. Such assumption does not affect the result in this paper qualitatively. Unlike default model, this paper abstracts from the lenders' problem and I do not require the expected repayment to match the risk premium on the bond. As a result, assuming $b_{t+j}=b_{t+1} \forall j>1$ in equations (5) and (6)) when calculating bond price does not jeopardize the idea I want to convey in this model.

Given a value of the bond duration parameter $\delta$, I first calculate the bond price for each combination of $\left(b^{\prime}, y_{T}\right)$. I use global non-linear methods to solve for the decision rules of the private agents' problem. The solution method is described in Baxter (1991) and involves iterating on the recursive Euler equations (11) in private agents' states $\left(b, y_{T}\right)$ until they converge. I first guess an asset decision rule two periods ahead $b^{\prime \prime}\left(b^{\prime}, y_{T}^{\prime}\right)$ and plug it into the 


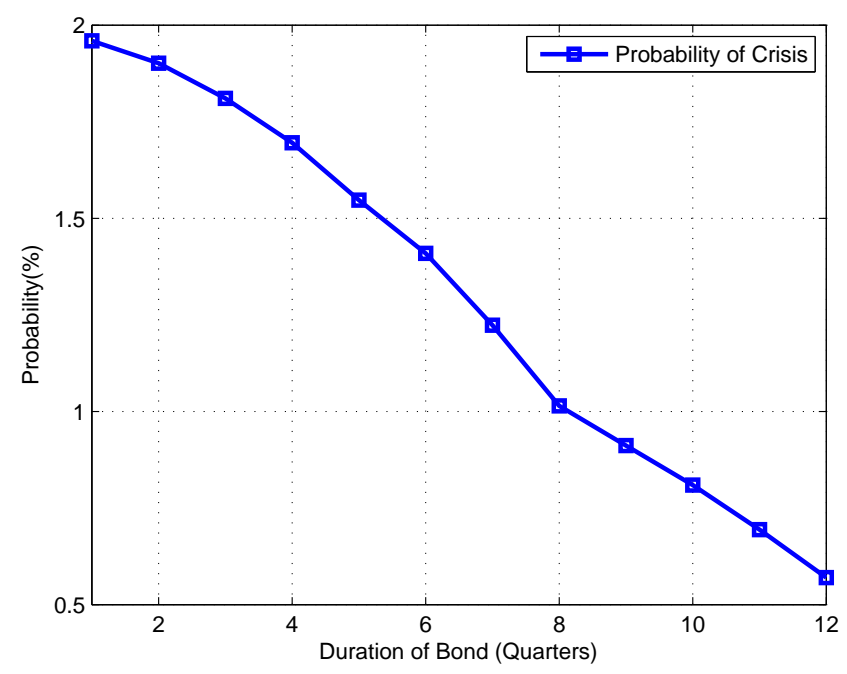

Figure 1: Probability of Crises as the Duration of Bond Changes

Euler equation (11). I then solve for the corresponding decisions on $\left\{b^{\prime}, c_{T}, c_{N}, p, c\right\}$ under each state $\left(b, y_{T}\right)$. Then I update the decision rule with $b^{\prime}\left(b, y_{T}\right)$ and plug it back into (11) to solve for the new decision rule. I repeat this process until the decision rule $b^{\prime}\left(b, y_{T}\right)$ converges at each state $\left(b, y_{T}\right)$.

To calculate the probability of crises in competitive equilibrium, I simulate the economy for 1,000,000 periods and abandon the first 1,000 periods, then I count the number of crisis events out of the remaining 999,000 periods. Following Benigno et al. (2013), I define a crisis in the model as an event which: (1) the borrowing constraint is binding and (2) Asset $_{t+1}-$ Asset $_{t}>3 \sigma\left(\right.$ Asset $_{t+1}-$ Asset $\left._{t}\right)$, where asset is defined as Asset $_{t}=q_{t}(1-\delta) b_{t}+b_{t}$. The second criterion holds when the capital outflow is greater than three standard deviations of the change of asset position under competitive equilibrium. The combination of these two criteria implies that a crisis occurs when the borrowing constraint is binding and there is a large current account reversal. The probability of a crisis occurring in a period is calculated as the total number of crisis periods divided by the total number of simulated periods.

\subsection{Results}

This section shows how probability of crises and welfare in competitive equilibrium vary with the duration of bond in this economy. Figure 1 shows the probability of crises in competitive equilibrium as the duration of bond varies from 1 quarter to 12 quarters. When the private agents can only issue one-period bonds $(\delta=1)$, the probability of crisis is $1.96 \%$ 




Figure 2: Consumption compensation that would leave private agents indifferent between living in an economy with one-quarter bond and living in an economy with the bond duration larger than one-quarter. The figure is constructed assuming that the initial debt level is equal to 0 .

and it is close to probability of crises found in Benigno et al. (2013) ${ }^{9}$. However, as the duration of bond gradually increases ( $\delta$ decreases), the probability of crises monotonically decreases in the duration of bond, as shown in figure 1. Specifically, when the duration of bond is increased from 1 quarter to 8 quarters, the probability of crises is reduced by nearly half and becomes $1.01 \%$. In addition, the probability of crises further drops to $0.56 \%$ when the private agents issue bonds with duration of 12 quarters. Therefore, this result implies that the model economy with longer duration bond suffers financial crises less frequently than the economy with one-period bond.

Next I compare the ex-ante welfare gain when the private agents issue the bonds with durations other than one-period. Figure 2 shows the consumption compensation that would leave private agents indifferent between living in an economy with one-quarter bond and living in an economy with a bond duration larger than one-quarter when the initial debt level is 0 . A positive number means that the private agents are worse off in the economy with one-quarter bond. As the duration of bond increases, the private agents enjoy the benefit from lower frequency of crises and the welfare gain gradually increases until it is maximized as the duration of bond reaches 7 quarters, where the maximized welfare gain is approximately $0.006 \%$ of permanent composite consumption. However, the welfare gain as a function of duration of bond is humped-shaped and the welfare gain decreases in the duration when the duration of bond exceeds 7 quarters.

\footnotetext{
${ }^{9}$ Benigno et al. (2013) also uses a model that is calibrated to quarterly data from Mexico and the probability of crises in their benchmark model is $2 \%$.
} 
Figures 1 and 2 show that even though the probability of crises monotonically decreases in the duration of bond, the welfare is not necessarily enhanced by having lower frequency of crises. Section 3.4 tries to interpret the hump-shaped welfare gain in figure 2 and discusses the trade-off of issuing bond that has duration larger than one-period.

\subsection{The Role of Debt Maturity}

Section 3.3 shows how probability of crises and welfare in competitive equilibrium change as the duration of bonds varies. This section discusses the trade-off of issuing long-term bonds in this economy with credit constraint.

\subsubsection{Cost of Long-term Bond}

Broner et al. (2013) studies why emerging economies borrow short-term bonds despite the presence of roll-over risks and it argues that countries borrow short-term because it is cheaper than borrowing long-term. Similar to Broner et al. (2013), in this model the average country interest rate increases in the duration of bonds in competitive equilibrium. As a result, the borrowing becomes so costly that the welfare decreases in the duration of bond when the duration of bond is larger than 7 quarters, as shown in figure 2.

Next I discuss why borrowing through bond with longer duration is more costly in this model. Figure 3 shows the coupon payment schedule for bonds with different duration, fixing the coupon payment at period $t+1$ equals one $\left(b_{t+1}=1\right)$. As shown in the graph, as the duration of bond increases ( $\delta$ decreases), the coupon payment decays at a slower pace over time and a higher proportion of the debt is repaid in more distant future. Notice that in equilibrium the country interest rate $r_{t}$ is higher than the exogenous international interest rate $r^{*}\left(r_{t}>r^{*}\right)$, due to the country borrowing premium part $\chi\left[\exp \left(-b_{t+1} /\left(r^{*}+\delta\right)\right)-1\right]$ in (5). The face value of the debt issued, $-b_{t+1} /\left(r^{*}+\delta\right)$ is defined as the present value of all future coupon payment discounted using the exogenous interest rate $r^{*}$. However, when private agents borrow, the proceeds they receive is the present value of all future coupon payment discounted by country interest rate $r_{t}$ instead of $r^{*}$. As a result, due to the difference between $r_{t}$ and $r^{*}$, the private agents need to issue debt with higher face value in order to receive the same proceeds when they borrow through bonds with longer duration.

To show this, the left panel of figure 4 shows the face value of bond $-b_{t+1} /\left(r^{*}+\delta\right)$ that private agents need to issue in order to finance 0.5 unit of consumption as the duration of bond varies. As shown in the plot, the private agents only need to issue bond with a face value of 0.503 when issuing one-period bond. However, the face value of bond that the private agents need to issue increases in the duration of bond. When the duration of bond is 

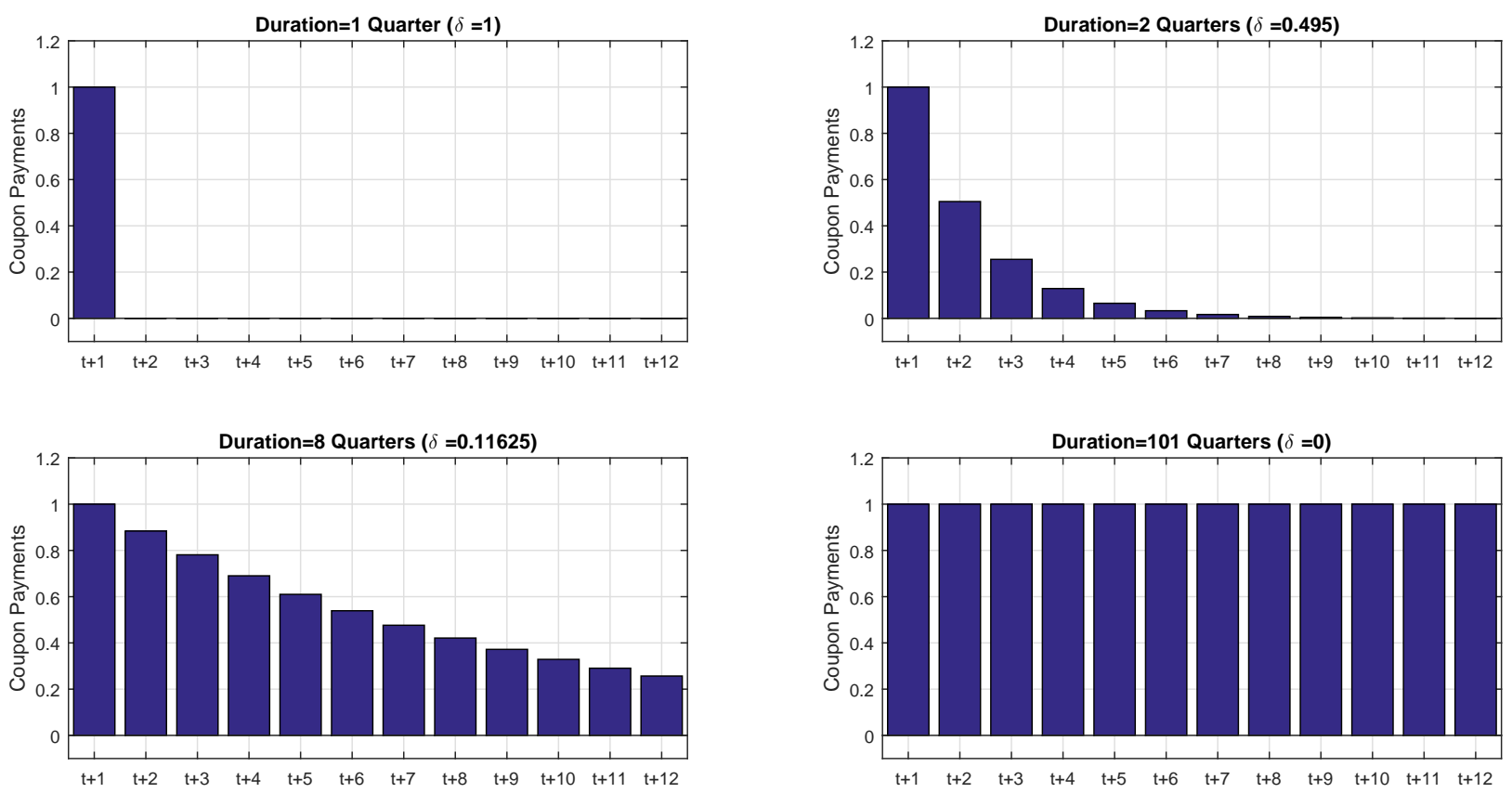

Figure 3: This figure shows the coupon payment schedule for bonds with different duration. To construct this plot, I fix the coupon payment equals one in period $t+1\left(b_{t+1}=1\right)$.

12 quarters, the private agents need to issue debt with face value of 0.543 in order to finance 0.5 unit of consumption. Also, equation (5) implies that the country interest rate increases in the face value of the aggregate bond issued in the small open economy. As a result, the private agents need to pay higher interest rate when the duration of bond is longer. The right panel of figure 4 shows that the average country interest rate monotonically increases in the duration of the bond in the economy. Therefore, it is welfare costly for the private agents to issue long-term bond if the duration of the bond becomes very long, as suggested by the hump-shaped welfare gain curve in figure 2 .

\subsubsection{Benefit of Long-term Bond}

The previous section argues that long-term bond may be welfare costly due to the high interest rate associated with long-term bond. However, the curve in figure 2 shows that in general there is a positive welfare gain when the duration of bond is larger than one quarter. This section discusses the benefit of borrowing through bonds with durations that are longer than one-period. As discussed in section 2.4, the private agents only need to rollover a fraction of the outstanding debt each period if they borrow through long-term bond. As a result, the effect of bond price externality is mitigated in the economies with long-term 

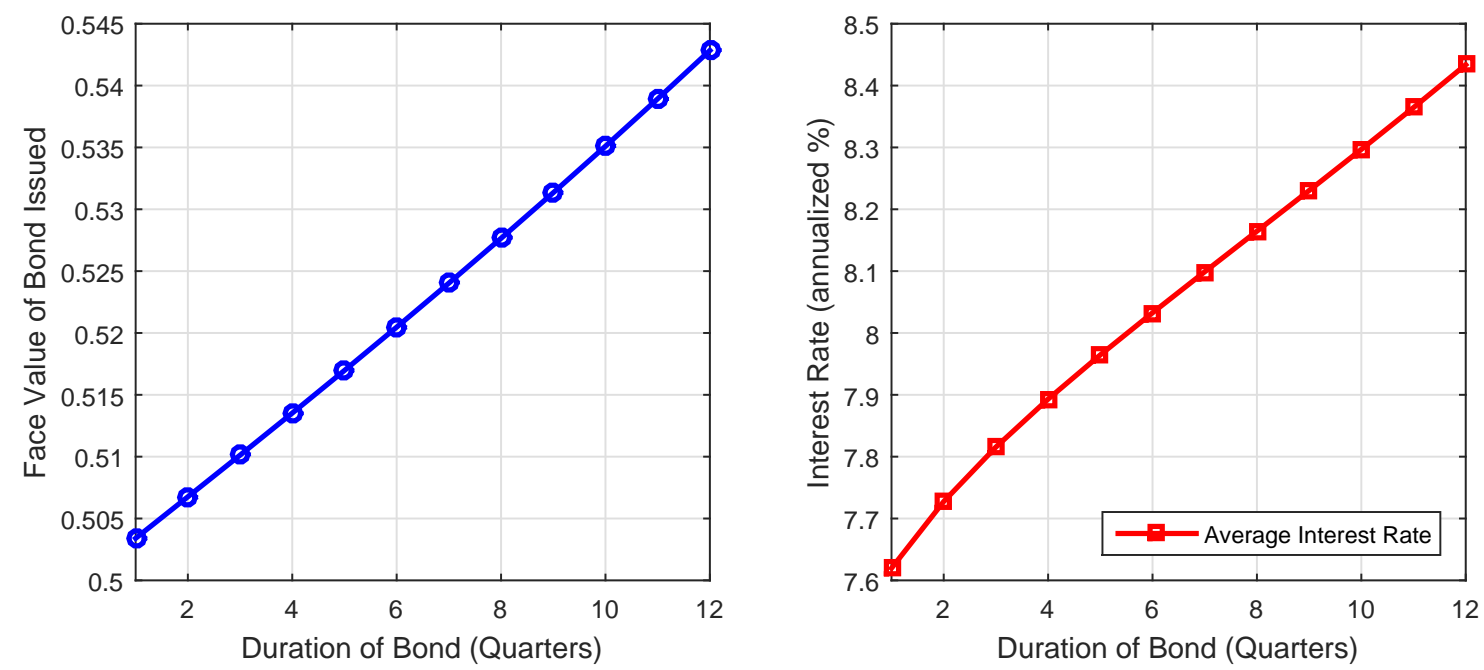

Figure 4: The left panel shows the face values of bond $-b_{t+1} /\left(r^{*}+\delta\right)$ that private agents need to issue, as the duration of bond changes, in order to finance 0.5 unit of consumption. The right panel shows the average country interest rate as the duration of bond in the economy changes.

bond. In the rest of this section, I investigate how long-term bond attenuates the effect of nontradable price externality.

Since the country interest rate is counter-cyclical, as specified in equation (5), the price of bond is thus pro-cyclical. Therefore, it can be recognized that the private agents' outstanding liability each period, $\left|b_{t}+q_{t}(1-\delta) b_{t}\right|$, is also pro-cyclical and negatively correlated with the tradable endowment. Specifically, the private agents' outstanding liability shrinks when an unfavorable endowment shock realizes. As a result, despite the fact that the coupon payments are non-contingent, long-term bond provides a hedge benefit against unfavorable shocks for the private agents and it can shift some of the risk toward the lenders. For comparison, when the private agents are borrowing through one-period bond, the liability $\left|b_{t}\right|$ is predetermined and such hedge benefit is not present. Figure 5 shows that the equilibrium standard deviation of tradable consumption decreases in the duration of bonds and it implies that the hedge benefit provided by the long-term bond enables private agents to better smooth consumption intertemporally.

The hedge benefit of long-term bond discussed above can mitigate financial amplification effect in this model. As described in section 2.3.3, the financial crises may arise endogenously when an unfavorable shock is realized and credit constraint is binding. A reduction in tradable consumption $c_{T, t}$ induced by the bad shock generates a reduction in $p_{t}$, which tightens the collateral constraint in equation (4). Consequently, the tightened collateral constraint further reduces $c_{T, t}$ and the vicious circle continues and generates financial crisis events. However, if the private agents borrow through long-term bond, the agents' outstanding li- 


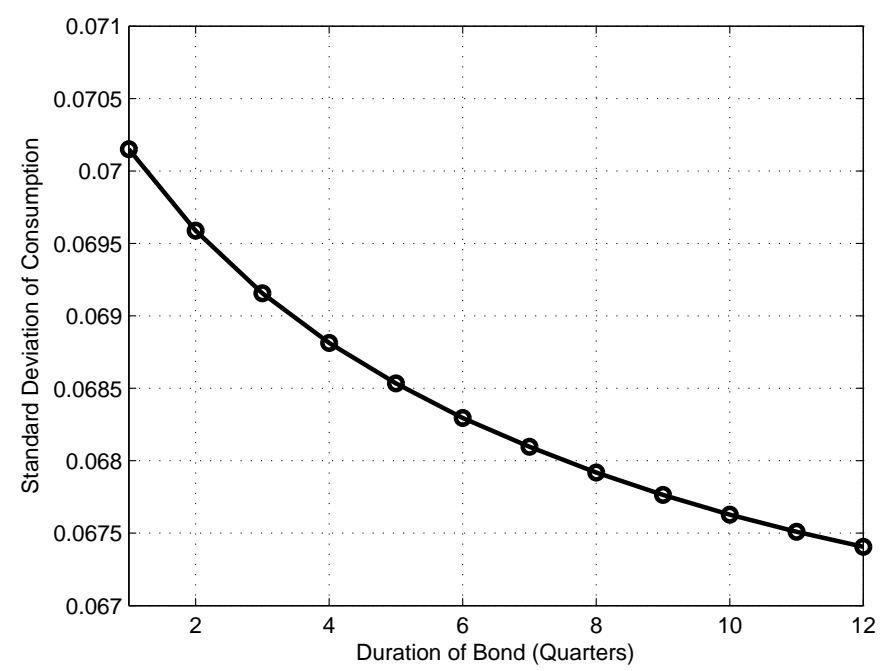

Figure 5: The standard deviation of tradable consumption as a function of the duration of bond.

ability also shrinks when an unfavorable realizes and thus the borrowing constraint is less likely to be binding. As a result, the hedge benefit provided by long-term bond can stop the vicious circle of financial amplification effect and reduce the probability of crises.

Next I argue the welfare gain of the insurance benefit of long-term bond is greater when the financial amplification is present in the model. Notice that the hedge benefit of long-term bond also exists in DSGE models without credit constraint and financial amplification effect. For example, Angeletos (2002) and Buera and Nicolini (2004) show that maturity structure can substitute for state-contingent debt and the theoretical conditions under which the complete market Ramsey allocation can be implemented with non-contingent debt of different maturities. In order to single out the welfare gain from the reduction of the probability of crises, I conduct two counterfactual experiments and eliminate the financial amplification effect in these two experiments. Then I calculate the ex-ante welfare gain when the private agents issue the bonds with different duration in these two counterfactual experiments. The definition of welfare gain is the same as in figure 2 and is defined as the consumption compensation that would make private agents indifferent between living in an economy with one-quarter bond and living in an economy with a bond duration larger than one-quarter.

In order to show the welfare gain from the reduction of financial amplification effect, I conduct two counterfactual experiments: (1) I manually fix the relative price of nontradable good $p_{t}$ at its average level. (2) I set the elasticity parameter between tradable and nontradable goods to -1 . In both counter factual experiments, I shut down the fluctuations of relative price of nontradable good and thus eliminate the financial amplification effect described in section 2.3.3. On the other hand, the cost of long-term bond is preserved in these 


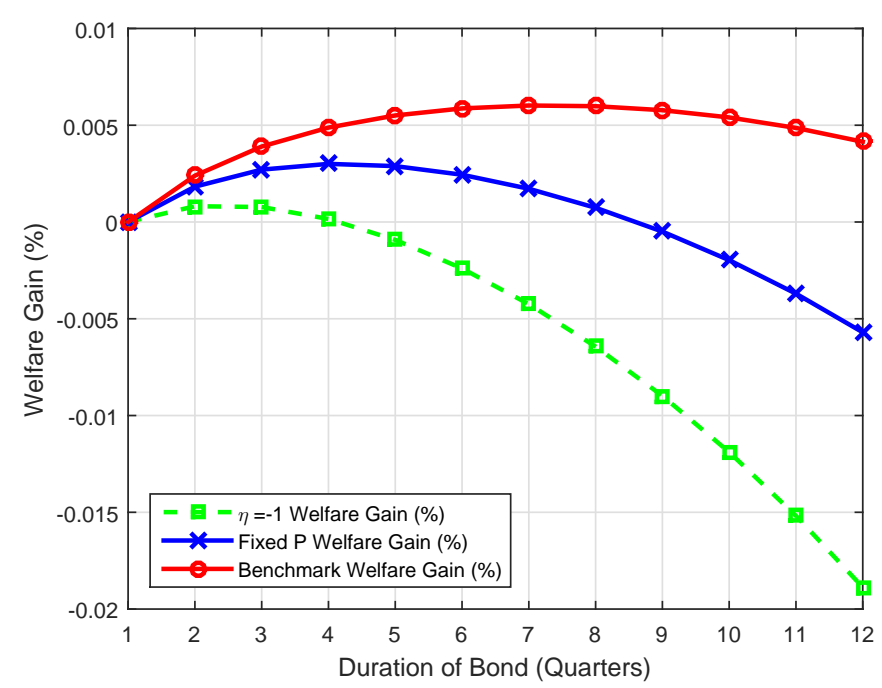

Figure 6: Consumption compensation that would leave private agents indifferent between living in an economy with one-quarter bond and living in an economy with a bond larger than one-quarter. The figure is constructed assuming that the initial debt level is equal to 0 . Red Line is welfare gain in benchmark model shown in figure 2. The blue line is constructed assuming the relative price of nontradable good $p_{t}$ is manually fixed. The green line is the case where $\eta=-1$.

two counterfactual experiments. The I calculate the welfare gain of having bonds with longer duration in these two counterfactual experiments. Figure 6 shows the welfare gain of living in economies with bonds with different durations compared to one-period bond in these two counterfactual experiments (the blue line and the green line, respectively), together with the welfare gain found in baseline model (red line). By comparing the welfare gain in these two counterfactual experiments to the one in benchmark model, I can discuss how the presence of financial amplification effect affect the hedge benefit of long-term bond.

There are two observations from figure 6. Firstly, all three curves are hump-shaped, but with different maximums. For the benchmark model, the welfare gain is maximized when the duration of bond is 7 quarters. For the two counterfactual experiments, the welfare gains are maximized at 4 quarters and 2 quarters, respectively. Secondly, the welfare gain of the benchmark model is higher than welfare gains in the two counterfactual experiments and the welfare gains become negative when the duration of bond becomes very long in the couterfactual experiments. The second observation implies that the insurance benefit is higher in the model with financial amplification since the hedge benefit can stop the vicious circle described in section 2.3.3. As a result, as suggested by the first observation, a regulator in an economy with financial amplification effect would choose a longer duration of bond than in a world without financial amplification effect. 


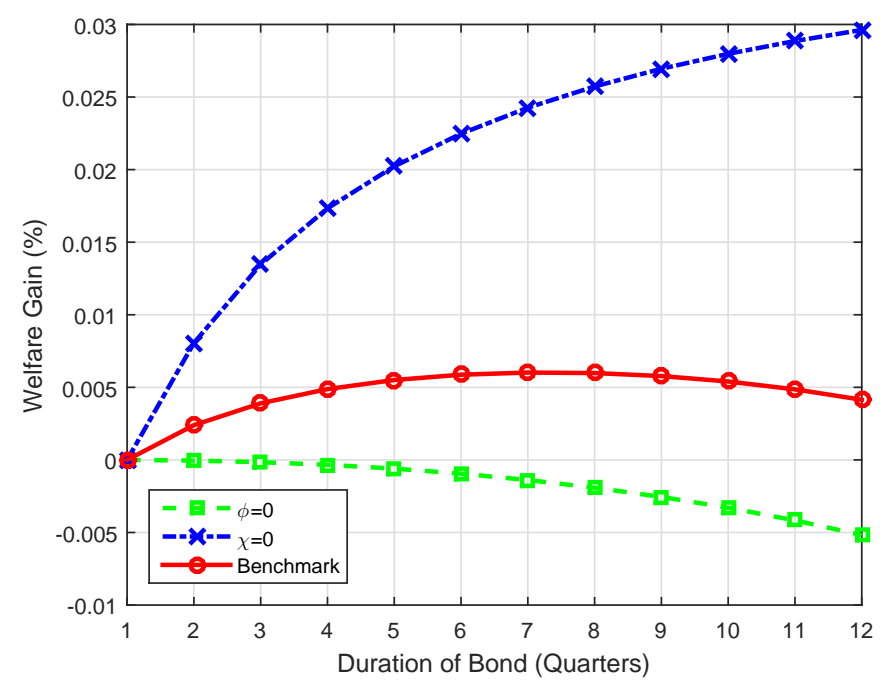

Figure 7: Consumption compensation that would leave private agents indifferent between living in an economy with one-quarter bond and living in an economy with a bond larger than one-quarter. Red Line is the welfare gain of competitive equilibrium shown in figure 2. Blue dotted line is constructed assuming $\chi=0$ and green dashed line $\phi=0$.

\subsubsection{Decomposition of Benefit and Cost}

In sections 3.4.1 and 3.4.2, I analyze the benefit and cost associated with long-term bond in a DSGE model with financial amplification effect. In order to show the benefit and cost more clearly, I conduct two more counterfactual experiments. In the first experiment, I set $\phi$ to 0 and thus shut down the counter-cyclical part in the country interest rate equation (5). Without the counter-cyclical interest rate, the hedge benefit of long-term bond vanishes. In the second experiment, I set $\chi$ to 0 and thus shut down the borrowing premium part in country interest rate equation (5). With $\chi$ set to be 0 , the country interest rate no longer increases in the aggregate debt level and thus long-term bond is no longer more expensive than short-term bond. I then calculate the welfare gain of living in the economies with bonds of different maturities and plot them in figure 7 and the definition of welfare gain is the same as in figures 2 and 6.

Figure 7 shows the welfare gain in baseline model and two counterfactual experiments described above. Blue dotted line shows the welfare gain in the case that $\chi=0$, green dashed line $\phi=0$ and red line is the welfare gain calculated in the baseline model. For the case that $\phi=0$, long-term bond can no longer provide hedge benefit to private agents but it is still more expensive to borrow long-term than short term. As a result, the welfare gain monotonically decreases in the duration of bond and the private agents are worse off living in economies with bond duration greater than one quarter. On the other hand, for the case 
where $\phi=0$, private agents can enjoy the hedge benefit brought by long-term bond without paying high interest for the hedge benefit. As a result, the welfare gain monotonically increases with the duration of bond when $\chi=0$. These two counterfactual experiments directly shows the benefit and cost of long-term bond in the model studied in this paper.

\subsection{Discussion of the Results}

The numerical result in this paper captures the largely agreed on trade-off between the insurance benefit and borrowing cost of long-term bond. However, the maximum welfare gain from longer duration of bond is relatively small in this paper. As shown in figure 2 , the maximum welfare gain is $0.006 \%$ of permanent consumption, while average welfare gains are $0.135 \%$ and $0.12 \%$ in Bianchi (2011) and Benigno et al. (2013). The reason of such discrepancy is that I assume the initial debt is 0 when calculating the welfare gain and Bianchi (2011) and Benigno et al. (2013) assume the initial debt level is around the area where the borrowing constraint is binding. As shown in Bianchi (2011), the welfare gain for this type model is state-contingent and is the greatest when the debt level is near the binding area. As a result, the zero-initial-debt assumption causes the welfare gain to be small in my numerical analysis.

In addition, the numerical analysis in this paper measures the welfare gain from varying the bond duration only. In reality, many emerging market economies not only regulate the maturity of capital inflows but also limit the total amount of capital inflows. In an alternative model, I follow Mendoza and Bianchi (2015) and assume that government imposes a constant tax rate $\tau$ on bond holding $b_{t+1}$. In this alternative model, I find that the welfare gain is $0.01 \%$ of permanent consumption when the government sets the tax rate at $1 \%$ and the bond duration at 15 quarters. This result implies that the government can further increase the welfare of the small open economy if it has more policy tools available. In this paper, I only focus on how the change of debt maturity may affect the stability and welfare of small open economies and leave the study of other policy tools to future research.

\section{Conclusion}

This paper develops a two-sector DSGE model with credit constraint in order to study the role of debt maturity in the context of financial amplification effect and sudden stop crises. Particularly, I try to use this model to justify the regulations on the maturity of capital inflows adopted by many emerging market economies. By featuring a financial friction and counter-cyclical country interest rate, this model captures the largely agreed on trade- 
off between the insurance benefit and borrowing cost of long-term bond. The quantitative analysis shows that long-term bond provides an insurance benefit that mitigates the financial amplification effect and reduces the frequency of sudden stop crises. On the other hand, bonds with longer duration also poses a higher cost to issue and thus can potentially be welfare costly.

The analysis in this paper hence provides a theoretical foundation for the regulations on short-term capital inflows that have been adopted by many emerging market economies. The quantitative analysis in this paper suggests that a carefully chosen bond duration in the economy can help prevent financial crises and enhance the welfare. One drawback of the model in this paper is that the duration of bond is set exogenously and the private agents cannot have bonds with different durations at the same time. In future research, it will be interesting to analyze the same research question in a model which the private agents are allowed to choose a portfolio of short-term and long-term assets. In addition, it would be an interesting research question to compare debt maturity regulation with other macro-prudential policy tools. 


\section{References}

Álvarez-Parra, F., L. Brandao-Marques, and M. Toledo (2013). Durable goods, financial frictions, and business cycles in emerging economies. Journal of Monetary Economics 60(6), $720-736$.

Angeletos, G.-M. (2002). Fiscal policy with noncontingent debt and the optimal maturity structure. The Quarterly Journal of Economics 117(3), 1105-1131.

Bengui, J. (2011). Systemic risk and inefficient debt maturity. Technical report, mimeo, University of Maryland.

Benigno, G., H. Chen, C. Otrok, A. Rebucci, and E. R. Young (2013). Financial crises and macro-prudential policies. Journal of International Economics 89(2), 453-470.

Bianchi, J. (2011). Overborrowing and systemic externalities in the business cycle. The American Economic Review, 3400-3426.

Bianchi, J. and E. G. Mendoza (2011). Overborrowing, financial crises and macroprudentialpolicy? IMF Working Papers, 1-53.

Broner, F. A., G. Lorenzoni, and S. L. Schmukler (2013). Why do emerging economies borrow short term? Journal of the European Economic Association 11(s1), 67-100.

Buera, F. and J. P. Nicolini (2004). Optimal maturity of government debt without state contingent bonds. Journal of Monetary Economics 51(3), 531-554.

Chatterjee, S. and B. Eyigungor (2012). Maturity, indebtedness, and default risk. The American Economic Review 102(6), 2674.

De Gregorio, J., S. Edwards, and R. O. Valdes (2000). Controls on capital inflows: do they work? Journal of Development Economics 63(1), 59-83.

Edwards, S. (1999). How effective are capital controls? The Journal of Economic Perspectives 13(4), 65-84.

Gallego, F., L. Hernández, K. Schmidt-Hebbel, et al. (1999). Capital controls in Chile: effective? Efficient? Number 59.

Hatchondo, J. C. and L. Martinez (2009). Long-duration bonds and sovereign defaults. Journal of International Economics 79(1), 117-125. 
Jeanne, O. and A. Korinek (2010). Managing credit booms and busts: A pigouvian taxation approach. Technical report, National Bureau of Economic Research.

Korinek, A. (2010). Regulating capital flows to emerging markets: An externality view. Available at SSRN 1330897.

Larraín, F., R. Labán, and R. A. Chumacero (1997). What determines capital inflows?: an empirical analysis for Chile, Volume 590. Harvard Institute for International Development, Harvard University.

Laurens, B. and J. Cardoso (1998). Managing capital flows: lessons from the experience of chile.

Magud, N. E., C. M. Reinhart, and K. S. Rogoff (2011). Capital controls: myth and reality-a portfolio balance approach. Technical report, National Bureau of Economic Research.

Mendoza, E. and J. Bianchi (2015). Optimal time-consistent macroprudential policy. Technical report, Society for Economic Dynamics.

Mendoza, E. G. (2002). Credit, prices, and crashes: Business cycles with a sudden stop. In preventing currency crises in Emerging Markets, pp. 335-392. University of Chicago Press.

Mendoza, E. G. (2010). Sudden stops, financial crises, and leverage. The American Economic Review $100(5), 1941-1966$.

Mendoza, E. G. and K. A. Smith (2002). Margin calls, trading costs, and asset prices in emerging markets: The finanical mechanics of the'sudden stop'phenomenon. Technical report, National Bureau of Economic Research.

Neumeyer, P. A. and F. Perri (2005). Business cycles in emerging economies: the role of interest rates. Journal of monetary Economics 52(2), 345-380.

Ostry, J. D., A. R. Ghosh, K. Habermeier, M. Chamon, M. S. Qureshi, and D. Reinhardt (2010). Capital inflows: The role of controls. Revista de Economia Institucional 12(23), 135-164.

Reinhart, C., T. Smith, et al. (1998). Too much of a good thing: the macroeconomic effects of taxing capital inflows. Managing capital flows and exchange rates: Perspectives from the Pacific Basin, 436-464. 
Uribe, M. and V. Z. Yue (2006). Country spreads and emerging countries: Who drives whom? Journal of international Economics 69(1), 6-36.

Valdés-Prieto, S. and M. Soto (1998). The effectiveness of capital controls: theory and evidence from chile. Empirica 25(2), 133-164. 